\title{
Transition to Competency-Based Medical Education: A Proposed Rollout Model
}

\section{Tripti K Srivastava', Lalitbhushan S Waghmare ${ }^{2}$, Alka T Rawekar ${ }^{3}$}

\section{ABSTRACT}

The Undergraduate Medical education curriculum in India is revised to competency-based Competency-Based Medical Education (CBME)) as per Graduate Medical Education (amendment 2019) from 2019 - 20 onwards. This manuscript suggest a Competency-Based Medical Education (CBME) Roll out model that can aid Medical Institutes across India to plan and implement this revised curriculum. The Model suggests formulation of various relevant committees, their terms of reference, Phases of roll out (Planning, implementation, Monitoring, Evaluation and Amendment) and GANTT chart. Implementation of reforms in a phasic manner with capacity building at relevant intervals, as suggested in the model, will provide a steady foundation to the revised curriculum and will ease the process of change.

Key Words: Competency-Based Medical Education, Indian Medical Graduate, Ethics and Communication.

\section{INTRODUCTION}

The Undergraduate Medical education curriculumin India is revised to competency-based as per Graduate Medical Education (amendment 2019) from 2019 to 20 onwards. ${ }^{1}$ The emphasis is to enable Indian Medical Graduate (IMG) to recognize "Health for all" as a National goal and fulfill his/her societal obligations. ${ }^{1}$ The revised curriculum is better aligned with Health professional attributes that are locally relevant and globally adaptive. The goal is that the IMG must be able to function in the roles of Clinician, Leader and Member of health care team, Communicator and Life long learner and Professional appropriately and effectively. Competency based learning includes designing and implementing medical education curriculum that focuses on the desired and observable ability in real life situations. Competency, per se, is defined as the habitual and judicious use of communication, knowledge, technical skills, clinical reasoning, emotions, values, and reflection in daily practice for the benefit of the individual and community being served. ${ }^{2}$

The regulatory body of Medical education suggests the broad framework of Competency-Based Medical Education (CBME). ${ }^{1,3}$ This manuscript suggests a comprehensive roll out plan by Jawaharlal Nehru Medical College, a constituent unit DMIMS, a deemed to be University, with flexibility of appropriate incorporations at local level to suit the need and context, keeping the broad framework intact. The various reforms that are contemplated with regards to CompetencyBased Medical Education (CBME) are as stated under;

1. Aligned and integrated curriculum

2. Foundation course

3. Early clinical exposure

4. Electives

5. Student - Doctor Method of Clinical Training

6. Certification of essential skills

7. Attitude, Ethics and Communication (AETCOM) skill module

8. Self directed learning

9. Co-curricular activities

10. Reforms in Formative, Internal and Summative Assessments

The rollout plan incorporates formulation of specific committees, terms of reference, phases of rollout, and Gantt chart.

\section{i. Composition of various committees:}

New COMPETENCY-BASED MEDICAL EDUCATION (CBME) curriculum must be phased out through the co-or-

\section{Corresponding Author:}

Tripti K Srivastava, Professor, Physiology, Jawaharlal Nehru Medical College, DMIMS (DU) Sawangi(M), Wardha, M.S., India.

ISSN: 2231-2196 (Print)

Received: 19.04 .2020
ISSN: 0975-5241 (Online)

Revised: 02.06 .2020
Accepted: 21.06 .2020
Published: 22.07 .2020 
dination of three significant committees viz.1. Departmental Curriculum Committee (DCC), 2. College Curriculum Committee (CCC) and 3. Expert Group (EG).

The Composition of the three committees is proposed as under;

a. Departmental Curriculum committee (DCC): The DCC committee must consist of three members who have undergone training in MCI recognized Basic course workshop and Curriculum Implementation and Support program (CISP).

Table 1: Departmental curriculum committee

\begin{tabular}{|c|c|c|}
\hline Sr. No & DCC composition & Role \\
\hline 1. & Head of Department & Chairman, DCC \\
\hline 2. & $\begin{array}{l}\text { Professor/Associate } \\
\text { Professor }\end{array}$ & $\begin{array}{l}\text { AIT ( Alignmentand } \\
\text { Integration) in-charge }\end{array}$ \\
\hline 3. & $\begin{array}{l}\text { Associate / Assistant } \\
\text { Professor }\end{array}$ & Member \\
\hline
\end{tabular}

b. College Curriculum Committee (CCC): The College Curriculum Committee must consist of six members, in accordance with BOGs, MCI guidelines as stated below;
Table 2: College curriculum committee

\begin{tabular}{lll} 
Sr. No & Designation & Representation \\
\hline 1 & Dean of the Institute & Chairman \\
2 & Professor, Preclinical & Preclinical \\
3 & Professor, Para clinical & Para clinical \\
4 & Professor, Medicine and allied & Medicine and allied \\
5 & Professor, Surgery and allied & Surgery and allied \\
6 & $\begin{array}{l}\text { Head, Medical Education unit } \\
\text { (MEU) }\end{array}$ & MEU \\
\hline
\end{tabular}

c. Expert group (EG): Four expert groups viz 1.Alignment Integration and ECE , 2. Assessment 3. Skills and 4.Electivesmust be formed. Each expert groups can consist of five members, each of whom have undergone training in $\mathrm{MCI}$ recognized Basic/revised basic course in Medical Education, Curriculum Implementation and Support Program and Advance course in ME/MPhil HPE. Each group must have a Co-convener and a member of CCC. The overall in-charge of the expert groups must be MEU co-coordinator. Each expert group will be responsible for operational monitoring and need based capacity building with regards to COMPETENCY-BASED MEDICAL EDUCATION (CBME). The terms of reference of various committees are identified in table no 3.

Table 3: Terms of reference of various committees

\begin{tabular}{|c|c|c|c|}
\hline $\begin{array}{l}\text { Name of the } \\
\text { committee }\end{array}$ & $\begin{array}{l}\text { Departmental curriculum } \\
\text { committee } \\
\text { (DCC) }\end{array}$ & $\begin{array}{l}\text { College curriculum committee } \\
\text { (CCC) }\end{array}$ & $\begin{array}{l}\text { Expert group } \\
\text { (EG) }\end{array}$ \\
\hline Purpose & $\begin{array}{l}\text { Implementation of the COM- } \\
\text { PETENCY-BASED MEDICAL } \\
\text { EDUCATION (CBME) in each } \\
\text { subject }\end{array}$ & $\begin{array}{l}\text { Overall in-charge of curricular deliv- } \\
\text { ery }\end{array}$ & $\begin{array}{l}\text { Operational monitoring and capacity } \\
\text { building }\end{array}$ \\
\hline Scope & $\begin{array}{l}\text { 1. Alignment and integration } \\
\text { 2. Develop learning and as- } \\
\text { sessment methods for each } \\
\text { subject andphase } \\
\text { 3. Prepare timetable for the } \\
\text { phase } \\
\text { 4. Obtain feedback and pro- } \\
\text { vides student support }\end{array}$ & $\begin{array}{l}\text { 1. Oversight and support of the cur- } \\
\text { ricular program } \\
\text { 2. Necessary authority and support } \\
\text { for the implementation of the cur- } \\
\text { riculum } \\
\text { 3. Preparation of reports etc. as } \\
\text { required by the Medical Council } \\
\text { of India }\end{array}$ & $\begin{array}{l}\text { 1. Monitoring of implementation of } \\
\text { COMPETENCY-BASED MEDICAL } \\
\text { EDUCATION (CBME) w.r.t } \\
\text { Alignment, Integration, ascendency } \\
\text { of competencies, ECE, Skill teaching, } \\
\text { Electives and assessment. } \\
\text { 2. Training and capacity building of } \\
\text { faculty as and when required }\end{array}$ \\
\hline Meeting & Fortnight & Monthly & Monthly \\
\hline Reporting & To CCC and EG & To College council & To College council \\
\hline
\end{tabular}




\section{ii. Phases of Roll-out:}

As mentioned in earlier paragraphs, the various reforms must be rolled out in five phases, as stated below;

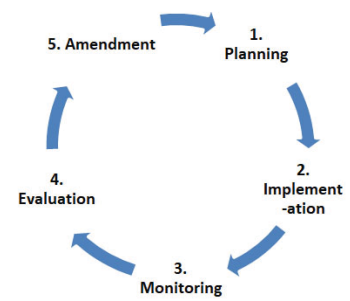

Figure 1: Phases of Competency-Based Medical Education (CBME) Rollout Plan, JNMC.

\section{1: Planning phase}

The first step to sustainable curricular reform is proper planning. The entire rollout plan must be planned with respect to desired tasks at hand, timeline and responsibility. Planning phase begins from the year of launch of first professional year with new curriculum and must continue prospectively for forthcoming professional years viz Professional year II, III and VI.
The planning phase comprises of two parallel levels of operation as depicted below;

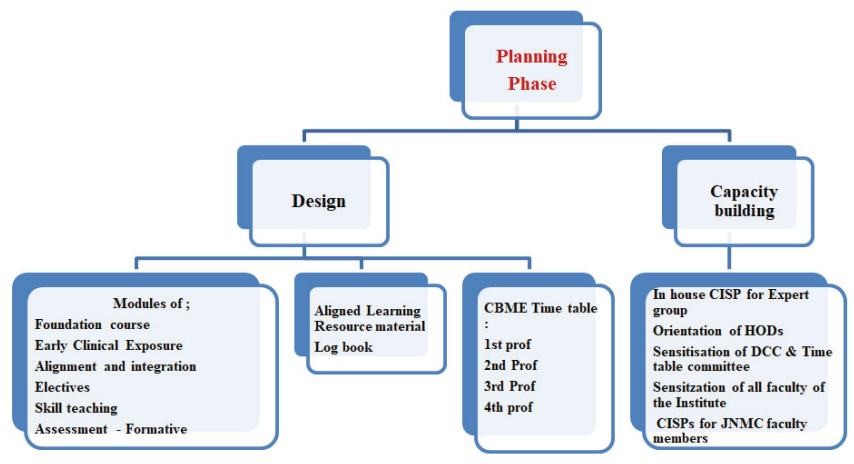

Figure 2: Series of events during planning phase of Competency-Based Medical Education (CBME).

The tables 1-4 gives operational details during planning phase for $\mathrm{I}^{\text {st }}-\mathrm{IV}^{\mathrm{th}}$ professional year, for the new curriculum launched in 2019 academic year, under the sections of Blueprinting and Capacity building.

\section{Table 4: Plan of Competency-Based Medical Education (CBME) for MBBS I ${ }^{\text {st }}$ Professional Year}

\section{Planning Phase}

First Professional Year

\section{a.

Blueprinting Tasks

Time Table

Foundation course module

ECE Module

Alignment and integration module

Formative assessment module

Log book

Aligned LRM

b. Capacity Building In house CISP for Expert group

Orientation of HODs

Sensitization of DCC ( $35 \%$ ) - for mapping competencies with objectives andTime table committee

In house CISP (MCI recognized)
Responsibility

Time table committee

Foundation course task group

AI and ECE Expert subgroupand DCC

Assessment Expert sub-group July 2019

Respective expert sub-group July 2019

JNMC task group

Convener and Co-conveners

Convener

Expert group

Expert group
May 2019

Timeline

$20^{\text {th }}$ April'19

May 2019

July 2019

Feb 2019

March 2019

(in College council)

April 2019

June' 2019 onwards 
Table 5 : Plan of Competency-Based Medical Education (CBME) for MBBS $2^{\text {nd }}$ Professional Year Planning Phase $2^{\text {nd }}$ Professional Year

\begin{tabular}{|c|c|c|c|}
\hline \multirow[t]{7}{*}{ a. Blueprinting } & Tasks & Responsibility & Timeline \\
\hline & Time Table & Time table committee & July'2o \\
\hline & $\begin{array}{l}\text { Alignment and integration mod- } \\
\text { ule }\end{array}$ & $\begin{array}{l}\text { AI and ECE Expert sub- } \\
\text { groupand DCC }\end{array}$ & November 2019 \\
\hline & $\begin{array}{l}\text { Clinical skill training module }-2^{\text {nd }} \\
\text { Prof }\end{array}$ & $\begin{array}{l}\text { Skill - Expert sub-groupand } \\
\text { DCC }\end{array}$ & Dec 2019 \\
\hline & $\begin{array}{l}\text { Formative assessment module for } \\
2^{\text {nd }} \text { Prof }\end{array}$ & Assessment Expert sub-group & Dec 2019 \\
\hline & Log book & Respective expert sub-group & Dec2019 \\
\hline & Aligned LRM & JNMC task group & Feb 2020 \\
\hline Capacity Building & $\begin{array}{l}\text { Sensitization of remaining faculty } \\
(35 \%) \text { - for mapping competen- } \\
\text { cies with objectives }\end{array}$ & Expert group & Sept 2019 \\
\hline & $\begin{array}{l}\text { In house CISP (MCI recognized) } \\
\text { for sensitized faculty }\end{array}$ & Expert group & Two CISPs in 2019-20 \\
\hline
\end{tabular}

Table 6: Plan of Competency-Based Medical Education (CBME) for MBBS III ${ }^{\text {rd }}$ Professional Year

Planning Phase Third Professional Year

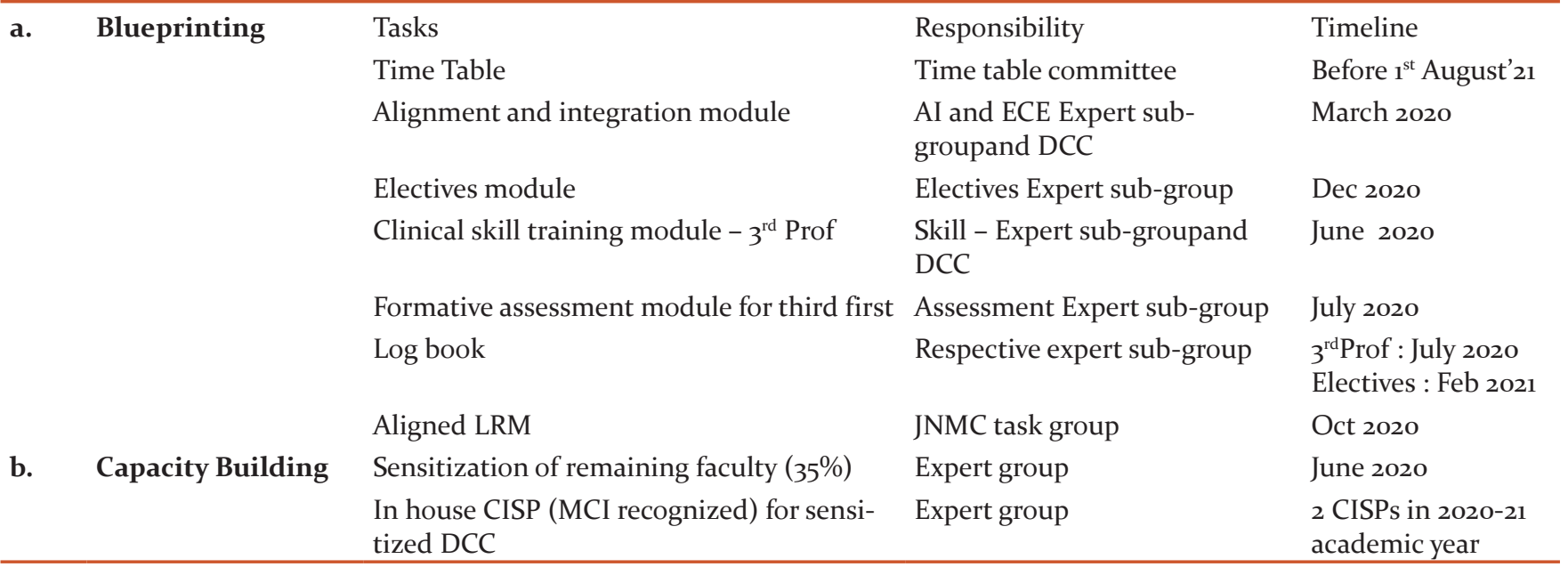

Table 7: Plan of Competency-Based Medical Education (CBME) for MBBS IV ${ }^{\text {th }}$ Professional Year

Planning Phase

Final Professional Year

a. Blueprinting Tasks

Time Table

Alignment and integration module

Clinical skill training module - Final Prof

Formative assessment module

Aligned LRM

Log book

b. Capacity Building
In house CISP for Expert group

Orientation of HODs

In house CISP (MCI recognized) for sensitized DCC
Responsibility

Time table committee

$\mathrm{AI}$ and ECE Expert sub-group

Skill - Expert sub-group

Assessment Expert sub-group

JNMC task group

Respective expert sub-group

Convener and Co-conveners

Convener

Expert group
Timeline

Before $1^{\text {st }}$ November' 22

July 2020

Sept 2020

Oct 2020

Oct 2020

Oct 2020

Feb 2019

March 2019 (in College council)

2 CISPs in 2021-22 academic year 
2. Implementation phase: Implementation of Competency-Based Medical Education (CBME) must be done prospectively and routed through Dean of the Institute and departmental curriculum committee headed by Head of Department. Need based capacity building must be taken up by Expert group as and when required.

Report: DCC must submit the report of Competency-Based Medical Education (CBME) implementation to $\mathrm{CCC}$ on quarterly basis. The compiled quarterly reports must be submitted to Medical Education Unit on annual basis which should be later submitted to Regulatory body for compliance.

\section{Monitoring Phase:}

The monitoring will be done at two levels, as stated below;

1. Mechanical monitoring: DCC

2. Operational monitoring: Expert group

It is proposed that DCC must meet fortnightly to discuss implementation of Competency-Based Medical Education (CBME) at the departmental level. The monthly report from DCC must be submitted to CCC. The CCC and expert group meetings should be held monthly to review the reports of DCC to ensure smooth implementation, necessary amendments, and relevant observations. The minutes of this monthly meeting must be itemized in the monthly college council meetings. This will enable formative evaluation of COMPETENCY-BASED MEDICAL EDUCATION (CBME) and allow intermediate corrections during the course. The same will be reviewed in quarterly joint college council meetings.

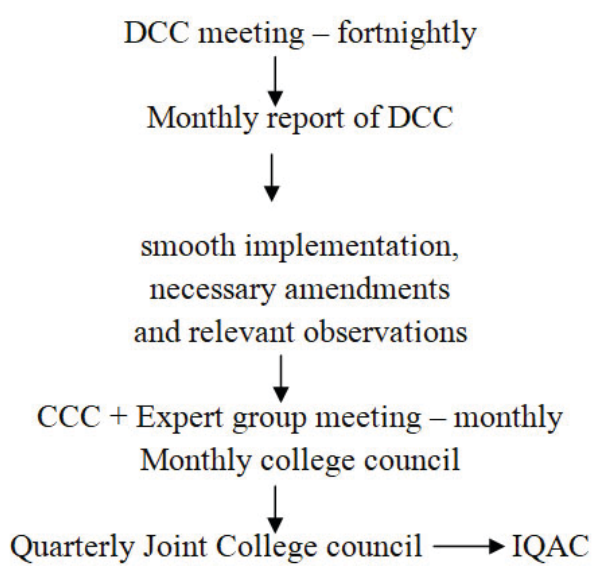

Figure 3: Monitoring mechanism for Competency-Based Medical Education (CBME) implementation.

4. Evaluation Phase: The entire roll out plan must be evaluated (formatively and summatively) by Internal Quality Assurance Cell (IQAC), as per the indicators identified in the planning and implementation phase.

5. Amendment Phase: The observations and suggestions of IQAC must be incorporated and aligned planning should be done before implementation.

\section{iii. COMPETENCY-BASED MEDICAL EDUCATION (CBME)Roll-out Time line:}

The entire roll out plan must have well defined deliverables with dedicated timeline as depicted in the GANNT chart for the COMPETENCY-BASED MEDICAL EDUCATION (CBME) launch in 2019 academic year.

Table 8: GANTT Chart for Competency-Based Medical Education (CBME) Roll out in 2019

\begin{tabular}{|c|c|c|c|c|c|c|c|}
\hline \multirow[b]{2}{*}{$\begin{array}{l}\text { Sr. } \\
\text { no }\end{array}$} & \multirow[b]{2}{*}{ Phase } & \multicolumn{6}{|c|}{ Academic Year } \\
\hline & & $2019-20$ & $2020-21$ & $2021-22$ & 2022-23 & $2023-24$ & $2024-25$ \\
\hline 1 & $\begin{array}{l}\text { Planning } \\
\text { Prof } 1\end{array}$ & $\begin{array}{l}\text { Modules : Foundation course } \\
\text { ECE Alignment and Formative } \\
\text { integration assessment } \\
\text { Prof } 1: \text { Aligned LRM }\end{array}$ & & & & & \\
\hline & Prof 2 & $\begin{array}{l}\text { Modules : Alignment and inte- } \\
\text { gration, Clinical skill training, } \\
\text { Formative assessment, Log book } \\
\text { Prof } 2 \text { : Aligned LRM }\end{array}$ & & & & & \\
\hline & Prof 3 & $\begin{array}{l}\text { Alignment and integration } \\
\text { module }\end{array}$ & $\begin{array}{l}\text { Modules : Electives, } \\
\text { Clinical skill training, } \\
\text { Formative assessment, } \\
\text { Log book } \\
\text { Phase } 1 \text { : Prof } 3 \text { : } \\
\text { Aligned LRM }\end{array}$ & & & & \\
\hline
\end{tabular}


Table 8: (Continued)

\begin{tabular}{|c|c|c|c|c|c|c|c|}
\hline \multirow[b]{2}{*}{$\begin{array}{l}\text { Sr. } \\
\text { no }\end{array}$} & \multirow[b]{2}{*}{ Phase } & \multicolumn{6}{|c|}{ Academic Year } \\
\hline & & 2019-20 & $2020-21$ & 2021-22 & $2022-23$ & $2023-24$ & $2024-25$ \\
\hline & Prof 4 & & $\begin{array}{l}\text { Module : Align- } \\
\text { ment and integration } \\
\text { Clinical skill training, } \\
\text { Formative assessment, } \\
\text { Log book, } \\
\text { Prof 4: Aligned LRM }\end{array}$ & & & & \\
\hline 2 & $\begin{array}{l}\text { Capacity } \\
\text { building }\end{array}$ & $\begin{array}{l}\text { In house CISP (MCI recognized) } \\
\text { for sensitized DCC }\end{array}$ & $\begin{array}{l}\text { Sensitization of re- } \\
\text { maining faculty }(35 \%) \\
\text { for mapping compe- } \\
\text { tencies with objectives, } \\
2 \text { CISPs (MCI recog- } \\
\text { nized) for sensitized } \\
\text { faculty }\end{array}$ & $\begin{array}{l}2 \text { CISPs } \\
\text { (MCI rec- } \\
\text { ognized) }\end{array}$ & $\begin{array}{l}2 \text { CISPs } \\
\text { (MCI rec- } \\
\text { ognized) }\end{array}$ & & \\
\hline 3 & $\begin{array}{l}\text { Implemen- } \\
\text { tation }\end{array}$ & Prof 1 & Prof 1 , Prof 2 & $\begin{array}{l}\text { Prof } 2 \\
\text { Prof } 3\end{array}$ & $\begin{array}{l}\text { Prof } 3 \\
\text { Electives } \\
\text { Prof } 4\end{array}$ & $\begin{array}{l}\text { Prof } 4 \\
\text { Internship }\end{array}$ & Internship \\
\hline 4 & $\begin{array}{l}\text { Monitor- } \\
\text { ing }\end{array}$ & $\begin{array}{l}\mathrm{DCC}, \mathrm{CCC}+ \\
\mathrm{EG}, \mathrm{CC}, \mathrm{JCC}\end{array}$ & $\begin{array}{l}\text { DCC , CCC+ } \\
\text { EG, CC, JCC }\end{array}$ & $\begin{array}{l}\text { DCC, } \\
\text { CCC+EC, } \\
\text { CC, JCC }\end{array}$ & $\begin{array}{l}\text { DCC, CCC } \\
+ \text { EC, CC, } \\
\text { JCC }\end{array}$ & $\begin{array}{l}\text { DCC, CCC } \\
+\mathrm{EC}, \mathrm{CC}, \\
\mathrm{JCC}\end{array}$ & $\begin{array}{l}\text { DCC, CCC } \\
+\mathrm{EC}, \mathrm{CC}, \\
\text { JCC }\end{array}$ \\
\hline 5 & Evaluation & IQAC & IQAC & IQAC & IQAC & IQAC & IQAC \\
\hline
\end{tabular}

Implication: Implementation of reforms in a phasic manner with capacity building at relevant intervals, as suggested in the model, will provide a steady foundation to the revised curriculum and will ease the process of change.

\section{CONCLUSION}

Any change should be weighed from multiple perspectives. The magnitude of change also defines the amount of input, resources and time. Bigger the change, more will be the time required for planning and leadership support. ${ }^{4}$ One key aspect involves involving various stakeholders as change agents and appraising them about the benefits of the Change. Competency Based Medical Education is one such change that requires careful planning, diligent implementation and robust monitoring. The proposed rollout plan, with its five distinct phases, can serve as a useful guide for educational leaders at various Medical schools to bring about this change with capacity building at one hand and administrative support at the other. The Interoperable systems that support information flow in number of directions is a hallmark of the proposed plan.

\section{ACKNOWLEDGEMENT}

Authors acknowledge the immense help received from the scholars whose articles are cited and included in references of this manuscript. The authors are also grateful to authors / editors / publishers of all those articles, journals and books from where the literature for this article has been reviewed and discussed.

\section{Conflict of Interest: Nil}

Source of Funding: Nil

\section{REFERENCES}

1. https://www.mciindia.org/CMS/e-gazette (last accessed on 25th April 2020)

2. Epstein RM, Hundert EM. Defining and assessing professional competence. JAMA. 2002;287(2):226-235.

3. Curriculum Implementation Support Program of the Competency Based Undergraduate Medical Education Curriculum, Medical Council of India, 2019

4. Bland CJ, Starnaman S, Wersal L, Moorhead-Rosenberg L, Zonia S, Henry R. Curricular change in medical schools: how to succeed. Acad Med 2000; 75:575-94 